УДК [631.563:635.156]:678.048

(C) 2013

Прісс О. П., Жукова В. Ф., кандидати сільськогосподарських наук

Таврійський державний агротехнологічний університет

\title{
ЗАЛЕЖНІСТЬ УРОЖАЙНОСТІ ТА ПОКАЗНИКІВ ЯКОСТІ ПЛОДІВ ТОМАТА ВІД ПОГОДНИХ УМОВ
}

\section{Рецензент - кандидат сільськогосподарських наук М. Є. Сердюк}

Досліджено вплив погодних умов на врожайність $i$ формування показників якості томатів, вирощених на краплинному зрошенні. Кореляційним аналізом встановлено сильну залежність суми активних температур при вирощуванні томатів та урожайності, виходу стандартної продукиії, вмісту сухих речовин у плодах. Визначено сильний позитивний зв'язок між кількістю опадів при вирощуванні та рівнем нітратів у плодах. Показано слабкий зв'язок між рівнем опадів і врожайністю. Виявлено сильний вплив відносної вологості повітря на вихід стандартної продукиї, вміст сухих речовин $i$ нітратів у плодах.

Ключові слова: плоди томата, урожайність, якість, погодні фактори.

Постановка проблеми. Формування якості плодів томата відбувається на рослині впродовж вегетаційного періоду і залежить від впливу різних абіотичних і біотичних факторів, індивідуальних для кожної фази онтогенезу [2, с. 496]. Тісна взаємодія культур 3 умовами навколишнього середовища вимагає забезпеченості теплом, вологою та сонячною енергією. Мінливість кліматичних показників корегує хімічний склад плодів, що відображається на їх якості. Агротехнічні заходи при вирощуванні томатів направлені на створення передумов для оптимального розвитку культури.

Аналіз останніх досліджень і публікацій, у яких започатковано розв'язання проблеми. Тепло $є$ визначальним фактором для темпів росту, тривалості вегетаційного періоду, плодоутворення, врожайності томатів [2, с. 495]. Оптимальна температура для їх розвитку: при проростанні насіння $22-23{ }^{\circ} \mathrm{C}$, але не нижче $10-11{ }^{\circ} \mathrm{C}$; у фазі цвітіння вдень не нижче $25^{\circ} \mathrm{C}$, вночі $12{ }^{\circ} \mathrm{C}$; при зав'язуванні плодів $22-25{ }^{\circ} \mathrm{C}$ та під час достигання $25^{\circ} \mathrm{C}$. Коливання температури на $5{ }^{\circ} \mathrm{C}$ вище або нижче оптимуму призводить до послаблення процесів життєдіяльності.

Вологозабезпеченість протягом вегетації впливає на продуктивність і якість томатів [5]. Оптимальний рівень вологості грунту $-70-80 \%$, повітря $-60-70 \%$ від повної вологості [4, с. 30].
Проте Південь України $є$ зоною недостатнього зволоження. Нестача природної відносної вологості повітря лімітує формування високих врожаїв томата, погіршує якість плодів. Зрошення $€$ обов'язковим агротехнічним прийомом процесі вирощування томатів, адже їх продуктивність у такому разі зростає на $42-77 \%$, проте на $4,8-6 \%$ знижується вміст сухих речовин у плодах $[6$, с. 9 ; с. 153$]$.

Вид грунту та рівень родючості в значній мірі визначають врожайність та якість плодів томата. Ефективно вирощувати томати можна на легких, родючих, достатньо аерованих грунтах із нейтральною кислотністю [2, с. 496 , с. 505]. Найбільш придатні для томата супіщані та суглинисті грунти. За оптимального зволоження грунту на врожайність і якість плодів найбільше впливає система живлення, яку регулюють використанням органічних і мінеральних добрив [5]. За внесення оптимальних доз добрив у плодах томата покращуються смакові та поживні властивості [5; 6, с. 14], але підвищується вміст нітратів [6, с. 153]. Відомо, що нітрати, які накопичуються в продукції впродовж вегетаційного періоду, генерують утворення токсичного, надзвичайно активного гідроксил-радикалу, який може пошкоджувати мембранну структуру клітин [8].

Мета і завдання досліджень. Метою досліджень було встановлення закономірностей впливу агрокліматичних факторів на формування показників якості плодів томата під час вегетації. Завдання досліджень - дати теоретичне обгрунтування і прогнозування врожайності та якості томатів при вирощуванні в умовах краплинного зрошення.

Матеріал і методика досліджень. Дослідження проводилися впродовж 2007-2011 рр. на базі лабораторії «Технологія первинної переробки і зберігання продуктів рослинництва» Таврійського державного агротехнологічного університету.

Плоди томата сорту Рио Гранде Оригинал вирощували в умовах відкритого грунту в ПП «Димура» Запорізької області. Грунт у господарстві чорноземи південні солонцюваті. У господарстві 
полив культури здійснювався за допомогою краплинного зрошення. У період масового плодоутворення вологість грунту була 80-85 \% НВ.

Математичну обробку результатів досліджень виконували за Б. А. Доспєховим та ін. [3], а також за допомогою комп'ютерної програми Microsoft Office Excel 2003.

Результати досліджень. Якість плодів томата широко варіює навіть у межах одного сорту. Це обумовлене багатьма факторами, а саме: грунтовими, погодно-кліматичними умовами, технологією вирощування. Недооцінка цих факторів призводить до зниження товарної якості продукції, що викликає значні комерційні збитки. Допускається, що залежно від специфіки року вирощування плоди томата можуть мати різні біохімічні та фізикомеханічні показники, проте вони повинні відповідати нормам і вимогам стандартів щодо зовнішнього вигляду, смаку і запаху, розміру плоду, ступеня стиглості, наявності дефектів [7].

Кореляційний аналіз показав сильний позитивний зв'язок $(\mathrm{r}=0,77-0,99)$ між сумою активних температур у процесі вирощування томатів і такими показниками як урожайність, вихід стандартної продукції, вміст сухих речовин (рис. 1). Між сумою активних температур i вмістом нітратів у плодах існує пряма залежність середньої сили.

Дослідженням впливу суми опадів на якісні показники томатів встановлено сильний позитивний зв'язок $(\mathrm{r}=0,94)$ між рівнем нітратів у плодах та кількістю опадів при вирощуванні (рис. 2). Кореляційна залежність між рівнем опадів і врожайністю показала слабкий прямий зв'язок ( $\mathrm{r}=0,17)$, що вказує на незначний вплив даного погодного фактора на якість плодів томата, поскільки томати вирощені на краплинному зрошенні. Крім того, кореляційним аналізом встановлено зв'язок середньої сили між рівнем опадів і виходом стандартної продукції ( $\mathrm{r}=0,61)$. Виявлена зворотна кореляція середньої сили між рівнем опадів та вмістом сухих речовин у плодах $(\mathrm{r}=-0,43)$. Зниження сили зв'язку також пояснюється вирощуванням із застосуванням краплинного зрошення.

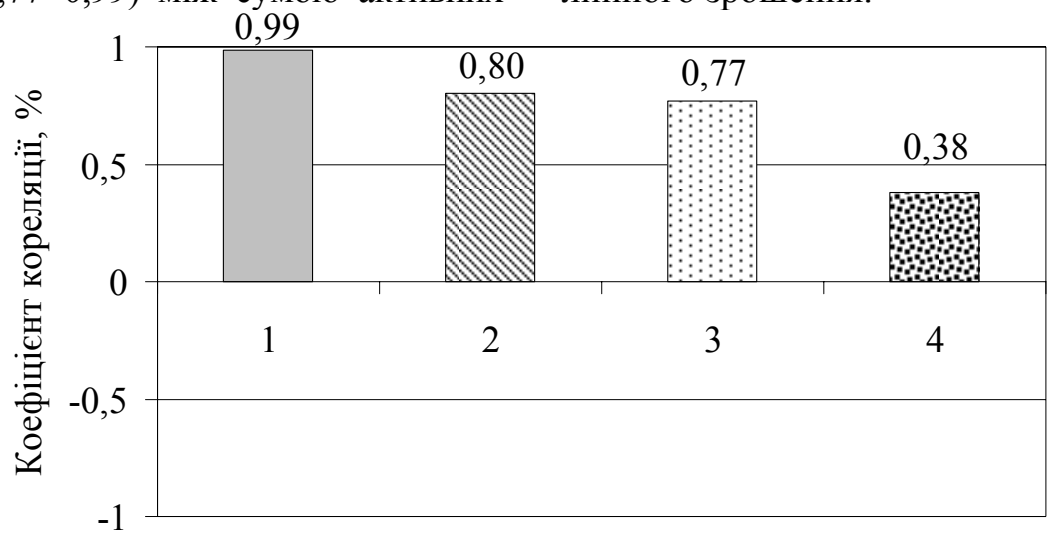

Рис. 1. Кореляційна залежність суми активних температур і якісних показників томатів (2007-2011 рр.): $\square$ - врожайність; $\mathbb{Q}$ - вихід стандартної продукції; - вміст сухих речовин; 图 - вміст нітратів.

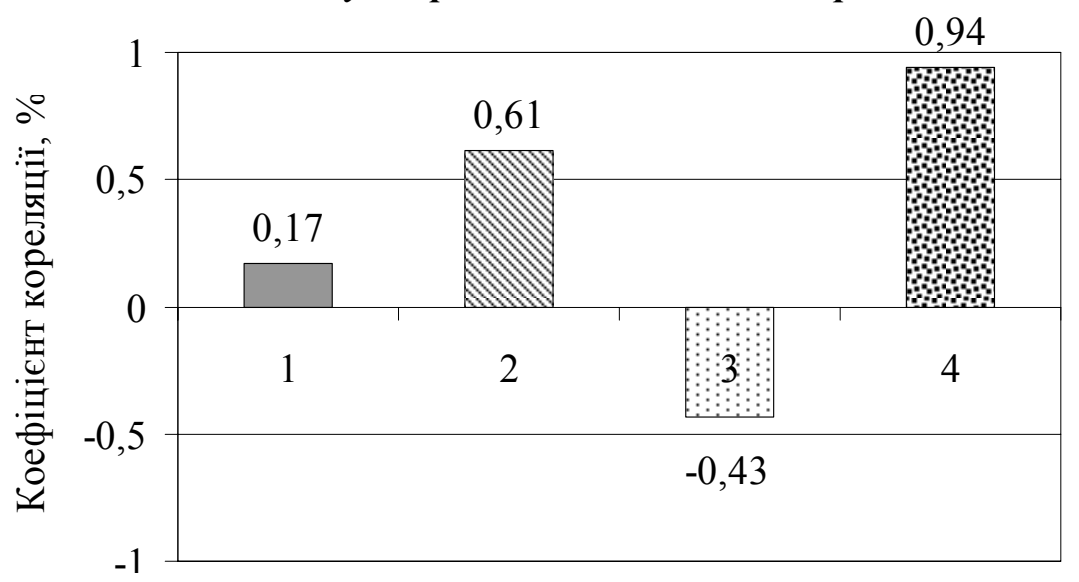

Рис. 2. Кореляційна залежність суми опадів і якісних показників томатів (2007-2011 рр.): $\square$-врожсайність; $\mathbb{Q}$ - вихід стандартної продукції; - вміст сухих речовин; 图 - вміст нітратів. 


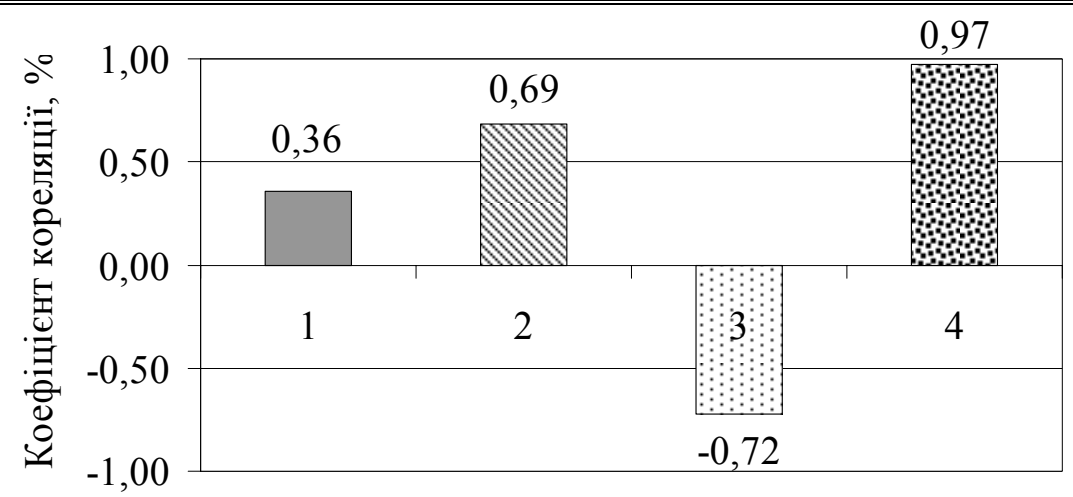

Рис. 3. Кореляційна залежність ВВП і якісних показників томатів (2007-2011 рр.):

$\square$-врожайність; $\mathbb{Q}$ - вихід стандартної продукції;

- вміст сухих речовин; 图 - вміст нітратів.

Для томатів характерний сильний прямий зв'язок між відносною вологістю повітря (ВВП) і виходом стандартної продукції $(\mathrm{r}=0,69)$, рівнем нітратів у плодах $(\mathrm{r}=0,97)$, а також сильний зворотний між ВВП та вмістом сухих речовин у плодах $(\mathrm{r}=-0,72)$ (рис. 3). Кореляційна залежність ВВП і врожайності знижується до середньої $(\mathrm{r}=0,36)$.

Висновки: 1. Погодні умови вирощування впливають на комплекс якісних показників плодів томата. Удосконалення технологій виробни-

\section{БІБЛІОГРАФІЯ}

1. Божко Л. Е. Радиационные факторы и продуктивность овощных культур / Л. Е. Божко // Український гідрометеожурнал. - 2007. - № 2. C. $105-118$.

2. Болотских A. С. Овощи Украины / А. С. Болотских. - Х. : Орбита, 2001. - 1088 с.

3. Доспехов Б. А. Методика полевого опыта / Б. А. Доспехов. - М. : Агропромиздат, 1985. $351 \mathrm{c}$.

4. Кравченко В. А. Помідор: селекція, насінництво, технології / В. А. Кравченко, О.В.Приліпка. - К. : Аграрна наука, 2007. - 404 с.

5. Куи Г. М. Получение качественной продукции томата в условиях орошения юга Украины. Актуальные проблемы эффективного использова- цтва томатів, яке передбачає застосування краплинного зрошення, управління живленням, дотримання сівозмін, контроль шкідливих організмів, дає можливість максимально реалізувати біологічний потенціал томатів i, таким чином, отримати продукцію високої якості.

2. Перспективою подальших досліджень у даному напрямі $\epsilon$ встановлення закономірностей змін фізіологічних і біохімічних показників плодів томата за зберігання залежно від агрокліматичних умов формування якості під час вегетації.

ния орошаемых земель / Г. М. Куц // Сборник научных статей. - Херсон, 1997. - С. 139-142.

6. Степанова I. М. Залежність врожаю та якості плодів посівного томата від сорту, добрив, густоти стояння рослин і зрошення в умовах Півдня України: Дис. ... канд. с.-г. наук: 01.04.18 / Інститут землеробства Української академії аграрних наук. - Херсон, 2005. - 177 арк.

7. Томати свіжі. Технічні умови : ДСТУ 3246-95. [Чинний від 1997-01-01]. - К. : Держспоживстандарт України, 1996. - 15 с.

8. Elstner E. F. Mechanisms of oxygen activation in different compartments of plant cells / E. F. Elstner// American Society of Plant Physiologists. 1991. - P. 13-25. 